\title{
Experimental infection of layer hens with a human isolate of Brachyspira pilosicoli
}

\author{
Abdollah Jamshidit and David J. Hampson

\section{Division of Veterinary and Biomedical Sciences, Murdoch University, Murdoch, Western Australia 6150, Australia}

Correspondence

David J. Hampson

d.hampson@murdoch.edu.au

Received 2 August 2002

Accepted 27 December 2002

\begin{abstract}
The anaerobic intestinal spirochaete Brachyspira pilosicoli commonly colonizes the large intestine of a number of species, including chickens and human beings. The purpose of the current study was to determine whether an isolate of $B$. pilosicoli recovered from an HIV-infected patient with diarrhoea could infect and cause disease in adult chickens. Over a 4-week period following experimental infection, a group of eight inoculated chickens showed a persistent and significant increase in faecal water content ( $\sim 6-7 \%)$. The faeces of three of the eight birds became culture-positive, and remained so. At post-mortem examination, no specific pathological changes were found, and no spirochaetal attachment to the caecal epithelium was observed. These findings confirm that $B$. pilosicoli strains can infect across species barriers and cause chronic mild diarrhoea in intact adult chickens.
\end{abstract}

\section{INTRODUCTION}

The anaerobic intestinal spirochaete Brachyspira pilosicoli has been isolated from the large intestine or faeces of many animal species, including pigs (Trott et al., 1996b), chickens (Stephens \& Hampson, 2001), dogs (Duhamel et al., 1998) and water birds (Oxberry et al., 1998). A pathognomonic feature of the colonization, seen in only some infected individuals, is the presence of a 'false brush border' made up of large numbers of spirochaetes attached by one end to the epithelium of the caecum, colon and/or rectum (Thomson et al., 1997). In pigs, B. pilosicoli causes porcine intestinal spirochaetosis, a common and widespread colonic infection of weaner and grower pigs, associated with loose faeces and poor growth rates (Trott et al., 1996b; Thomson et al., 1997). In poultry, infection with B. pilosicoli is common in adult layer and broiler breeder flocks (Stephens \& Hampson, 1999), and has been associated with delayed and reduced egg production and increased faecal moisture content (Stephens \& Hampson, 2002a). B. pilosicoli also colonizes humans: in developing countries, including Oman (Barrett, 1990) and Papua New Guinea (Trott et al., 1997a), B. pilosicoli has been shown to colonize around $30 \%$ of individuals, whilst in developed countries it occurs at around this prevalence in rural Aboriginal people in Australia (Lee \& Hampson, 1992), in male homosexuals (Trivett-Moore et al., 1998) and in patients infected with human immunodeficiency virus (HIV) (Käsbohrer et al., 1990). In comparison, the spirochaete is rarely isolated from the faeces of the

tPresent address: Department of Food Hygiene, Faculty of Veterinary Medicine, Ferdowsi University of Mashad, Mashad, Iran.

Abbreviation: HIV, human immunodeficiency virus. general population in developed countries (Tompkins et al., 1986; Lee \& Hampson, 1992; Brooke et al., 2001). In humans, the colonization has been linked to a number of symptoms including chronic diarrhoea, rectal bleeding, pseudo-appendicitis and lower abdominal discomfort (Gad et al., 1977; Douglas \& Crucioli, 1981; Rodgers et al., 1986; Heine et al., 2001). More severe invasive cases have also been described in both immunocompromised and immunocompetent individuals, with intestinal spirochaetes being observed in enterocytes, goblet cells, macrophages and Schwann cells, and associated in some cases with epithelial ulceration and necrosis, and crypt abscessation (Antonakopoulos et al., 1982; Guccion et al., 1995; Padmanabhan et al., 1996). Intestinal spirochaetes resembling $B$. pilosicoli have been observed invading the colon and liver of a homosexual man with HIV, who was suffering from choleostatic hepatitis (Kostman et al., 1995). Isolates of B. pilosicoli have also been recovered from the bloodstream of immunocompromised individuals in Europe and the USA, some of whom have had bloody diarrhoea (Lambert \& Goursot, 1982; FourniéAmazouz et al., 1995; Trott et al., 1997b; Kanavaki et al., 2002).

Evidence for the zoonotic spread of B. pilosicoli remains equivocal. There are a few examples where the same or very similar strains of the spirochaete have been found in humans and dogs living in the same environment (Koopman et al., 1993; Rayment et al., 1997; Trott et al., 1998). There is experimental evidence that B. pilosicoli can be transmitted between animal species, and human strains of $B$. pilosicoli have been used to experimentally infect pigs (Trott et al., 1996a), mice (Sacco et al., 1997) and day-old chicks (Dwars et al., 1992; Trott et al., 1995; Muniappa et al., 1996). Recently, 
we reported the infection of adult layer and breeder chickens with strains of B. pilosicoli isolated from chickens (Jamshidi \& Hampson, 2002; Stephens \& Hampson, 2002a). In the current study, we report the successful colonization of layer hens with a strain of B. pilosicoli isolated from an HIVinfected patient with diarrhoea (Mikosza et al., 2001).

\section{METHODS}

Ethics. This experiment was conducted with the approval of the Murdoch University Animal Ethics Committee.

Experimental birds. Sixteen ISA Brown laying pullets were purchased from a commercial breeder at 18 weeks of age, and were housed in individual cages with mesh floors located in an environmentally controlled $\left(25^{\circ} \mathrm{C}\right)$ facility. The birds were subjected to $12 \mathrm{~h}$ artificial light each day. They fed $a d$ lib on a commercial wheat and vegetableprotein diet (Wesfeeds). At 37 weeks of age they were allocated randomly to two groups of eight, with each group housed in their individual cages in separate rooms.

Experimental infection. B. pilosicoli human strain HIV3AB2 was obtained as a frozen stock culture from the collection held by the Reference Centre for Intestinal Spirochaetes at Murdoch University. The strain was originally isolated from an Australian HIV-infected patient with histological intestinal spirochaetosis and chronic diarrhoea (Mikosza et al., 2001). The strain was thawed and grown in Kunkle's anaerobic broth medium (Kunkle et al., 1986) at $37^{\circ} \mathrm{C}$ on a rocking platform until early exponential-phase growth was achieved, when the spirochaetes were actively motile. Growth and absence of contamination were monitored by examining aliquots taken at daily intervals under a phase-contrast microscope. At 38 weeks of age, eight birds in one group were inoculated orally via a crop tube with $2 \mathrm{ml}$ actively growing culture, on three consecutive days. The broth contained approximately $10^{8}$ bacterial cells $\mathrm{ml}^{-1}$. The eight uninfected control birds in the other room were sham-inoculated with sterile broth.

Experimental monitoring. The chickens were weighed on entry to the experiment at 38 weeks of age and at weekly intervals thereafter. Eggs were collected daily and weighed. At weekly intervals, starting immediately before the experimental infection, aluminium foil was placed under the cage of each bird and individual faecal samples were collected after $1 \mathrm{~h}$. Portions (approx. $1 \mathrm{~g}$ ) were weighed, then dried to constant weight to determine the faecal moisture content. At weekly intervals, starting immediately before the experimental infection, cloacal swabs were taken from each chicken at the time of weighing. A proportion of the faeces was resuspended in PBS and examined under a phase-contrast microscope. The swabs were inoculated onto Trypticase soy agar (BBL) supplemented with $5 \%$ defibrinated ovine blood, $400 \mu \mathrm{g}$ spectinomycin $\mathrm{ml}^{-1}$ and $25 \mu \mathrm{g} \mathrm{ml}^{-1}$ each of colistin and vancomycin (Jenkinson \& Wingar, 1981). Plates were incubated in an anaerobic environment $\left(94 \% \mathrm{~N}_{2} / 6 \% \mathrm{CO}_{2}\right.$ ) generated by Gaspak Plus sachets (BBL), and growth was examined by phase-contrast microscopy after 5 and 10 days. The presence of spirochaetes was initially identified by the appearance of a zone of weak $\beta$-haemolysis surrounding a low flat haze of bacterial growth. Spirochaetal growth was subcultured, and isolated cells were then subjected to a PCR protocol which specifically amplifies a $439 \mathrm{bp}$ segment of the 16S rRNA gene of B. pilosicoli (Atyeo et al., 1998; Mikosza et al., 1999, 2001). The PCR products were subjected to electrophoresis in $1.5 \%$ agarose gel, stained by immersion for $30 \mathrm{~min}$ in ethidium bromide solution, and viewed over UV light.

Post-mortem examination. Five weeks after infection, the birds were killed by cervical dislocation and subjected to post-mortem examination. The caeca and colon were opened to look for gross changes, a section of one caecum was placed in Bouin's fixative for subsequent histological examination, and a swab was taken from the wall of the other caecum for spirochaete culture. These were processed as for faecal samples. After $4 \mathrm{~h}$ fixation, the caecal tissue was washed three times in $50 \%$ ethanol and transferred to $70 \%$ ethanol. The tissue was processed through to paraffin blocks, sectioned at $4 \mu \mathrm{m}$ and stained with haematoxylin and eosin.

Analysis. The two-tailed $t$-test was used to determine the significance of differences between the infected and control groups in terms of weekly group bird weights, faecal moisture content and egg production.

\section{RESULTS}

Before experimental infection, the faeces of both groups of birds were of similar consistency and moisture content (Table 1). One week following infection, the faeces of the infected birds had become softer and less well-formed, and they remained so throughout the experiment. Each week after infection until the end of the experiment, the faecal moisture content of the infected group of birds was significantly greater than that of the control birds, being on average around $6-7 \%$ wetter (Table 1 ). Over the experimental period, there were no significant differences in bird weights, weekly egg numbers or egg weights between the two experimental groups.

At post-mortem, the caecal size and contents varied between birds, with some caeca being small and empty, and others being large and full of contents of varying consistency. There were no consistent group effects. The mucosal surface of all the caeca examined were grossly normal, and histological examination failed to show any pathological changes. No end-on attachment of spirochaetes to the luminal surface of the caecal enterocytes was observed in any of the birds.

No spirochaetes were detected in the faeces of any of the birds before experimental infection, or in the uninfected birds at any time. Spirochaetes, which were all subsequently identified as B. pilosicoli by PCR amplification, were isolated from the faeces of three of the eight infected birds 1 week after infection, and in the same birds at weekly intervals to the end of the experiment. B. pilosicoli was also isolated from the caecal wall of these three birds at post-mortem. Occasional

Table 1. Mean \pm standard deviation of faecal moisture content $(\%)$ in chickens infected with a human strain of $B$. pilosicoli and in uninfected control birds

\begin{tabular}{|lccc|}
\hline $\begin{array}{l}\text { Weeks post- } \\
\text { infection }\end{array}$ & Infected & Control & $\boldsymbol{P}_{\text {-value }}$ \\
\hline 0 & $78 \cdot 93 \pm 7 \cdot 47$ & $78 \cdot 87 \pm 5 \cdot 91$ & 0.987 \\
1 & $83.08 \pm 5 \cdot 32$ & $77 \cdot 50 \pm 4 \cdot 32$ & $0 \cdot 037$ \\
2 & $87 \cdot 34 \pm 4 \cdot 83$ & $81.02 \pm 3 \cdot 72$ & $0 \cdot 011$ \\
3 & $84.84 \pm 4 \cdot 07$ & $77 \cdot 74 \pm 5 \cdot 32$ & $0 \cdot 010$ \\
4 & $84.98 \pm 4 \cdot 78$ & $78.05 \pm 7 \cdot 69$ & $0 \cdot 001$ \\
\hline
\end{tabular}

${ }^{\star}$ Comparisons using a two-tailed $t$-test. 
spirochaetes were observed in the faeces of the other experimentally infected birds, but these were not isolated.

\section{DISCUSSION}

In this study, a strain of B. pilosicoli isolated from an HIVinfected patient with histological intestinal spirochaetosis and chronic diarrhoea, was shown to colonize the caeca of three of eight experimentally inoculated adult chickens. This colonization was persistent, extending over a 4 -week period. Prolonged colonization, averaging 4 months, is a feature of natural B. pilosicoli infection in humans (Trott et al., 1998). Some colonization probably occurred in the other five infected birds, because spirochaetes were observed in their faeces, and the whole infected group showed an increase in faecal moisture content following experimental infection. The sensitivity of detection of B. pilosicoli by faecal culture is not particularly high $\left[>5 \times 10^{4}\right.$ cells $\left(\mathrm{g}\right.$ faeces) $\left.{ }^{-1}\right]$ (Atyeo et al., 1998), and it is possible that the other birds would have been recorded as colonized if PCR techniques had been applied to the primary growth on the isolation plates, or even directly to the faeces (Atyeo et al., 1998; Mikosza et al., 2001). The relatively low colonization rate as assessed by culture $(38 \%)$ is consistent with what has been reported in adult chickens that have been experimentally inoculated with chicken strains of B. pilosicoli (Jamshidi \& Hampson, 2002; Stephens \& Hampson, 2002a). Layer hens can be made considerably more susceptible to colonization with $B$. pilosicoli if they receive 50 p.p.m. zinc bacitracin in their diets (Jamshidi \& Hampson, 2002). It is assumed that this antimicrobial agent disrupts the normal caecal microflora, reducing colonization resistance and hence enhancing spirochaetal colonization. In the current experiment, this manipulation was not undertaken as one of the aims of the experiment was to judge the susceptibility to infection of adult birds with intact intestinal microflora. It was previously known that day-old chicks could be colonized with human strains of B. pilosicoli (Dwars et al., 1992; Trott et al., 1995; Muniappa et al., 1996), but this colonization may be facilitated by the presence of a poorly developed large intestinal microflora in young birds. Colonization of human beings with $B$. pilosicoli could also potentially be enhanced by disruptions to the large intestinal microflora through oral antimicrobial treatments, or following other enteric infections or dietary changes (Hopwood et al., 2002).

The successful colonization of adult birds with a human isolate of B. pilosicoli supports previous experimental findings that this spirochaete can infect across species boundaries. Previously, a human isolate of $B$. pilosicoli has been used to experimentally infect a human being (Oxberry et al., 1998), but no attempts have been made to infect humans with animal isolates of $B$. pilosicoli, to determine whether this spirochaete has zoonotic potential.

Infection with $B$. pilosicoli did not alter egg production or cause weight loss. It is possible that had infection occurred at an earlier age, or if colonization had been more prolonged, such changes may have been seen. No pathological changes were observed in the caeca of colonized birds, but this is not a unique situation as it has been recorded in chickens infected with a chicken strain of $B$. pilosicoli (Jamshidi \& Hampson, 2002; Stephens \& Hampson, 2002a), and in mice infected with a human strain of B. pilosicoli (Sacco et al., 1997). Furthermore, only one caecal site from three culture-positive birds was examined at post-mortem. Traditionally, diagnosis of intestinal spirochaetosis in humans has been made by histological examination of colorectal biopsies. In the absence of spirochaetal attachment and histological changes, diagnosis is therefore reliant on specialized microbiological examination, and this is only available in some veterinary laboratories. As a consequence of these diagnostic difficulties, infection with $B$. pilosicoli may be much more widespread than has been appreciated.

The group of birds that was experimentally infected developed a chronic change in faecal consistency. The $6-7 \%$ mean increase in faecal moisture content resulted in the faeces becoming more sloppy and poorly formed, although watery diarrhoea was not observed. Wet faeces are a major problem to the egg-production industry, resulting in faecal staining of egg shells, problems with mechanical cleaning of sheds, increased odour and attraction of flies (Stephens \& Hampson, 2001). The mechanisms involved in producing such diarrhoea are unknown, especially as in this case there was no obvious spirochaetal attachment to the epithelium or disruption of the microvilli. The small but significant changes in faecal water content are consistent with the situation described in pigs and chickens naturally infected with $B$. pilosicoli, as well as in humans with intestinal spirochaetosis (Lee \& Hampson, 1992; Hopwood et al., 2002; Stephens \& Hampson, 2002b).

\section{ACKNOWLEDGEMENTS}

This study was supported by a grant from the National Health and Medical Research Council of Australia. Thanks are due to Sophy Oxberry for excellent technical assistance.

\section{REFERENCES}

Antonakopoulos, G., Newman, J. \& Wilkinson, M. (1982). Intestinal spirochaetosis: an electron microscopic study of an unusual case. Histopathology 6, 477-478.

Atyeo, R. F., Oxberry, S. L., Combs, B. G. \& Hampson, D. J. (1998). Development and evaluation of polymerase chain reaction tests as an aid to diagnosis of swine dysentery and intestinal spirochaetosis. Lett Appl Microbiol 26, 126-130.

Barrett, S. P. (1990). Intestinal spirochaetes in a Gulf Arab population. Epidemiol Infect 104, 261-266.

Brooke, C. J., Clair, A. N., Mikosza, A. S. J., Riley, T. V. \& Hampson, D. J. (2001). Carriage of intestinal spirochaetes by humans: epidemiological data from Western Australia. Epidemiol Infect 127, 369-374.

Douglas, J. G. \& Crucioli, V. (1981). Spirochaetosis: a remediable cause of diarrhoea and rectal bleeding? BMJ 283, 1362.

Duhamel, G. E., Trott, D. J., Muniappa, N., Mathiesen, M. R., Tarasiuk, K., Lee, J. I. \& Hampson, D. J. (1998). Canine intestinal spirochetes consist of Serpulina pilosicoli and a newly identified group provisionally designated "Serpulina canis" sp. nov. J Clin Microbiol 36, 2264-2270. 
Dwars, R. M., Davelaar, F. G. \& Smit, H. F. (1992). Infection of broiler chicks (Gallus domesticus) with human intestinal spirochaetes. Avian Pathol 21, 559-568.

Fournié-Amazouz, E., Baranton, G., Carlier, J. P. \& 7 other authors (1995). Isolations of intestinal spirochaetes from the blood of human patients. J Hosp Infect 30, 160-162.

Gad, A., Willén, R., Furugård, K., Fors, B. \& Hradsky, M. (1977). Intestinal spirochaetosis as a cause of longstanding diarrhoea. Uppsala J Med Sci 82, 49-54.

Guccion, J. G., Benator, D. A., Zeller, J., Termanini, B. \& Saini, N. (1995). Intestinal spirochetosis and acquired immunodeficiency syndrome: ultrastructural studies of two cases. Ultrastruct Pathol 19, 15-22.

Heine, R. G., Ward, P. B., Mikosza, A. S. J., Bennett-Wood, V., RobinsBrowne, R. M. \& Hampson, D. J. (2001). Brachyspira aalborgi infection in four Australian children. J Gastroenterol Hepatol 16, 872-875.

Hopwood, D. E., Pethick, D. W. \& Hampson, D. J. (2002). Increasing the viscosity of the intestinal contents stimulates proliferation of enterotoxigenic Escherichia coli and Brachyspira pilosicoli in weaner pigs. $\mathrm{Br} \mathrm{J}$ Nutr 88, 523-532.

Jamshidi, A. \& Hampson, D. J. (2002). Zinc bacitracin enhances colonization by the intestinal spirochaete Brachyspira pilosicoli in experimentally infected layer hens. Avian Pathol 31, 293-298.

Jenkinson, S. R. \& Wingar, C. R. (1981). Selective medium for the isolation of Treponema hyodysenteriae. Vet Rec 109, 384-385.

Kanavaki, S., Mantadakis, E., Thomakos, N., Pefanis, A., MatsiotaBernard, P., Karabela, S. \& Samonis, G. (2002). Brachyspira (Serpulina) pilosicoli spirochetemia in an immunocompromised patient. Infection 30, 175-177.

Käsbohrer, A., Gelderblom, H. R., Arasteh, K., Heise, W., Grosse, G., L'age, M., Schonberg, A., Koch, M. A. \& Pauli, G. (1990). Intestinale spirochätose bei HIV-infektion. Dtsch Med Wochenschr $\mathbf{1 1 5}$, 1499-1506.

Koopman, M. B. H., Käsbohrer, A., Beckmann, G., van der Zeijst, B. A. M. \& Kusters, J. G. (1993). Genetic similarity of intestinal spirochetes from humans and various animal species. J Clin Microbiol 31, 711-716.

Kostman, J. R., Patel, M., Catalano, E., Camacho, J., Hoffpauir, J. \& DiNubile, M. J. (1995). Invasive colitis and hepatitis due to previously uncharacterized spirochetes in patients with advanced human immunodeficiency virus infection. Clin Infect Dis 21, 1159-1165.

Kunkle, R. A., Harris, D. L. \& Kinyon, J. M. (1986). Autoclaved liquid medium for propagation of Treponema hyodysenteriae. J Clin Microbiol 24, 669-671.

Lambert, T. \& Goursot, G. (1982). Diarrhée aiguë avec hémocultures et coprocultures positives à Tréponema. Med Malad Infect 12, 276-278.

Lee, J. I. \& Hampson, D. J. (1992). Intestinal spirochaetes colonizing aborigines from communities in the remote north of Western Australia. Epidemiol Infect 109, 133-141.

Mikosza, A. S. J., La, T., Brooke, C. J., Lindboe, C. F., Ward, P. B., Heine, R. G., Guccion, J. G., de Boer, W. B. \& Hampson, D. J. (1999). PCR amplification from fixed tissue indicates frequent involvement of Brachyspira aalborgi in human intestinal spirochetosis. J Clin Microbiol 37, 2093-2098.

Mikosza, A. S. J., La, T., Margawani, K. R., Brooke, C. J. \& Hampson, D. J. (2001). PCR detection of Brachyspira aalborgi and Brachyspira pilosicoli in human faeces. FEMS Microbiol Lett 197, 167-170.

Muniappa, N., Duhamel, G. E., Mathiesen, M. R. \& Bargar, T. W. (1996). Light microscopic and ultrastructural changes in the ceca of chicks inoculated with human and canine Serpulina pilosicoli. Vet Pathol 33, $542-550$
Oxberry, S. L., Trott, D. J. \& Hampson, D. J. (1998). Serpulina pilosicoli, waterbirds and water: potential sources of infection for humans and other animals. Epidemiol Infect 121, 219-225.

Padmanabhan, V., Dahlstrom, J., Maxwell, L., Kaye, G., Clarke, A. \& Barratt, P. J. (1996). Invasive intestinal spirochetosis: a report of three cases. Pathology 28, 283-286.

Rayment, S. J., Barrett, S. P. \& Livesley, M. A. (1997). Sub-specific differentiation of intestinal spirochaete isolates by macrorestriction fragment profiling. Microbiology 143, 2923-2929.

Rodgers, F. G., Rodgers, C., Shelton, A. P. \& Hawkey, C. J. (1986). Proposed pathogenic mechanism for the diarrhea associated with human intestinal spirochetes. Am J Clin Pathol 86, 679-682.

Sacco, R. E., Trampel, D. W. \& Wannemuehler, M. J. (1997). Experimental infection of $\mathrm{C} 3 \mathrm{H}$ mice with avian, porcine, or human isolates of Serpulina pilosicoli. Infect Immun 65, 5349-5353.

Stephens, C. P. \& Hampson, D. J. (1999). Prevalence and disease association of intestinal spirochaetes in chickens in eastern Australia. Avian Pathol 28, 447-454.

Stephens, C. P. \& Hampson, D. J. (2001). Intestinal spirochaete infections of chickens: a review of disease associations, epidemiology and control. Anim Health Res Rev 2, 83-91.

Stephens, C. P. \& Hampson, D. J. (2002a). Experimental infection of broiler breeder hens with the intestinal spirochaete Brachyspira (Serpulina) pilosicoli causes reduced egg production. Avian Pathol 31, 169-175.

Stephens, C. P. \& Hampson, D. J. (2002b). Evaluation of tiamulin and lincomycin for the treatment of broiler breeders experimentally infected with the intestinal spirochaete Brachyspira pilosicoli. Avian Pathol 31, 299-304.

Thomson, J. R., Smith, W. J., Murray, B. P. \& McOrist, S. (1997). Pathogenicity of three strains of Serpulina pilosicoli in pigs with a naturally acquired intestinal flora. Infect Immun 65, 3693-3700.

Tompkins, D. S., Foulkes, S. J., Godwin, P. G. R. \& West, A. P. (1986). Isolation and characterisation of intestinal spirochaetes. J Clin Pathol 39, 535-541.

Trivett-Moore, N. L., Gilbert, G. L., Law, C. L. H., Trott, D. J. \& Hampson, D. J. (1998). Isolation of Serpulina pilosicoli from rectal biopsy specimens showing evidence of intestinal spirochetosis. J Clin Microbiol 36 261-265.

Trott, D. J., McLaren, A. J. \& Hampson, D. J. (1995). Pathogenicity of human and porcine intestinal spirochaetes in one-day-old specificpathogen-free chicks: an animal model of intestinal spirochetosis. Infect Immun 63, 3705-3710.

Trott, D. J., Huxtable, C. R. \& Hampson, D. J. (1996a). Infection of newly weaned pigs with human and porcine strains of Serpulina pilosicoli. Infect Immun 64, 4648-4654.

Trott, D. J., Stanton, T. B., Jensen, N. S., Duhamel, G. E., Johnson, J. L. \& Hampson, D. J. (1996b). Serpulina pilosicoli sp. nov., the agent of porcine intestinal spirochetosis. Int J Syst Bacteriol 46, 206-215.

Trott, D. J., Combs, B. G., Mikosza, A. S. J. \& 7 other authors (1997a). The prevalence of Serpulina pilosicoli in humans and domestic animals in the Eastern Highlands of Papua New Guinea. Epidemiol Infect 119 369-379.

Trott, D. J., Jensen, N. S., Saint Girons, I., Oxberry, S. L., Stanton, T. B., Lindquist, D. \& Hampson, D. J. (1997b). Identification and characterization of Serpulina pilosicoli isolates recovered from the blood of critically ill patients. J Clin Microbiol 35, 482-485.

Trott, D. J., Mikosza, A. S. J., Combs, B. G., Oxberry, S. L. \& Hampson, D. J. (1998). Population genetic analysis of Serpulina pilosicoli and its molecular epidemiology in villages in the Eastern Highlands of Papua New Guinea. Int J Syst Bacteriol 48, 659-668. 